УДК $1: 316.3+340.12: 94(477)$

DOI: $10.26693 /$ ahpsxxi2019.01.058

\title{
НАРОДНИЙ РУХ УКРАЇНИ: ПРИЧИНИ ВИНИКНЕННЯ ТА НАСЛІДКИ ДІЯЛЬНОСТ
}

\author{
Iгор Поліuук, \\ e-mail: i_polischuk@ukr.net \\ ORCID: https://orcid.org/oooO-OOO1-6864-4425 \\ Національний юридичний університет імені Ярослава Мудрого, \\ Украӥна, 61024, м. Харків, вул. Пушкінсъка, 77
}

У статті розкриваються причини, основні періоди та наслідки діяльності Народного Руху Украйни. Розглядаються програмні засади партї «Народний Рух України» на сучасному етапі. В історій НРУ виділяються два основні етапи: 1) від заснування в 1989 р. до прийняття Конституиї в 1996 р. - активна політична діяльність, великий вплив на державотворчий процес; 2) з 1996 р. - спадання активності та втрата впливу на основні політичні процеси. Загалом Народний Рух Украӥни став компромісною формулою утворення організованої народної опозииї для кадрів КПУ. Основним історичним наслідком діяльності НРУ як масового громадського об’єднання було проголошення державної незалежності Украӥни, але він не спромігся стати демократичною партією влади за нових історичних умов. На сучасному етапі Народний Рух Украӥни перетворився на класичну національно-консервативну партію, яка мало впливає на сучасний політичний процес в Украӥні.

Ключові слова: Народний Рух Украӥни, перебудова, незалежність Украӥни, демократизація, політичний транзит, геополітика

Постановка проблеми. Україна демонструє доволі специфічну траєкторію політичного транзиту на пострадянському та, в цілому, на постсоціалістичному просторі. Нелінійність та суперечливість даного процесу, наявність наочних реверсів чи відкатів на шляху демократизації України змушують вчергове замислитись про генезу новітнього національно-визвольного руху та основні фактори, що спричинили унезалежнення та відмову від прокомуністичного концепту розвитку. Народний Рух України як масовий антикомуністичний та антиімперський суб'єкт у другій за масштабами радянській республіці безперечно виступає головним рушійним чинником революційних подій на зламі 80-90-х років ХХ ст. у колишньому СРСР. Події кінця 1980-х- початку 1990-х рр. в Україні визначають як «національна революція»1. Вона мала внутрішньополітичний та зовнішньополітичний аспект. Перший полягає у тому, що українці після довгих років перебування у радянській імперії нарешті звернулися до своєї національної ідеї, відроджуючи зруйновану національну самоідентифікацію. Національна ідея - це форма ментального осягнення нацією свого психологічно-культурного змісту, тобто характерного темпераменту, здібностей, нахилів, звичок, звичаїв тощо․

Другий, зовнішньополітичний для України чинник виявляється у тому, що друга за чисельністю в СРСР українська нація через тривалий історичний проміжок заявила про своє право на політичне самовизначення через побудову власної суверенної національної держави, чим детонувала Радянський Союз, який без участі України перетворювався на фікцію.

\footnotetext{
1 Чигрінов, B.I., Поліщук, I.О. (2006). Державотворча традиція украӥни: політикокультурний вимір. Харків: ХІБМ, 246.

2 Калиновський, Ю.Ю. (2016). Національна ідея як ціннісна детермінанта державотворчого процесу в Україні. Вісник Національного університету «Юридична академія Украӥни імені Яролава Мудрого». Серія: Філософія, 1 (28), 100.
} 
Існує й третій, геополітичний аспект української національної революції. Вона цілком вписується у хвилю «бархатних революцій» у тогочасному світі. Половина світу, колишні комуністичні держави Євразї, шукали шляхів будівництва демократичних систем урядування з нуля3. Звичайно, демократичне урядування в країнах Східної Європи навряд чи відновлювалося з нуля, адже у тій чи іншій мірі воно спиралося на міцність чи слабкість національної демократичної традиції. Там, де радянська автократія мала обмежений і недовготривалий вплив (Польща, Чехія, колишня Югославія та ін.), демократичні перетворення мали динамічний та інтенсивний характер. У країнах Балтії (які називали «радянським заходом») демократичний транзит теж мав доволі результативні обриси. В Україні ж перехід до демократії збігся у часі з іншими масштабними трансформаціями: відновленням національної державності та ринковими реформами в економіці. Це не могло не позначитися на якості та швидкості транзитивних процесів у різних сферах соціального життя.

Глобальні суспільно-політичні процеси у Східній Європі і на теренах СРСР у останніх десятиліттях XX ст.: розпад соціалістичного табору - країн Варшавського Договору, Ради Економічної Взаємодопомоги, розпад СРСР, відновлення державності низки країн на теренах Радянського Союзу, утворення нової - сучасної політичної конфігурації Європи і Євразї̈, відбувалися під проводом соціально-політичних і національно-демократичних рухів у окремих країнах. «Солідарність» у Польщі, «Саюдіс» у Литві, Національні та Народні Фронти у низці республік СРСР (зокрема, на Кавказі), Народний Рух України були промоутерами цих масштабних, доленосних процесів4. Безумовно першим масовим політичним об’єднанням в Україні був Народний Рух України за перебудову5.

Розробленість теми у науковій літературі. Розглядаючи наукову бібліографію нашої теми, слід зазначити, що дослідники здебільшого зверталися до таких проблем: історичні витоки появи Народного Руху України (НРУ) (Бондаренко (2006), Гай-Нижник (2012), Барановська (2010), Пустовіт (2010), діяльність Народного Руху з розробки національної програми соціально-політичного розвитку України (Гарань (1993), Журавський (1995), її практичної реалізації (Литвин (1994), Бойко (1996), роль Народного Руху у формуванні багатопартійної системи України (Базовкін (1991), Богомаз (1992), Деревінський (2010), місце і роль НРУ у розвитку українського національно-визвольного руху (Білецький (2009), Слюсаренко, Томенко (1997), взаємодія НРУ з українською діаспорою (Тиский (2001), історія Ради Національностей НРУ (Бураковський (1995), аналіз помилок керівництва НРУ у політичному процесі України (Кравчук (2009), Каспрук (2009), Лавринович (2018), геополітичний контекст місії НРУ (Рябоконь (2014). У цілому слід наголосити на тому, що у модерній історичній та політичній науці утворився доволі великий масив літератури, у якій досліджується поява та результати діяльності Народного Руху України. Проте у цих наукових розвідках знаходимо здебільшого більш чи менш ретельну хронологію розвитку НРУ як історичного феномену та доволі суб'єктивний, поверховий, фрагментарний аналіз причин політичного занепаду цієї організації.

Звідси головною метою даної статті $\epsilon$ розкриття сутнісних причин появи та основних політичних результатів діяльності Народного Руху України як непересічного історичного явища на теренах колишнього Радянського Союзу.

Історичні умови та причини виникнення Народного Руху України. Спочатку визначимо понятійний зміст громадських рухів та організацій, до яких належав Народний Рух України від свого заснування. Громадська організація - це добро-

\footnotetext{
3 Патнам, Р.Д, Леонарді, Р., Нанетті, Р.Й. (2001). Творення демократіӥ: традицї громадянської активності в сучасній Італії. Київ: Видавництво Соломії Павличко «Основи», 15.

4 Білецький, В. (2009, 10 вересня). Народний Рух України як історичне явище. Новости Донбасса. Retrieved from http://novosti.dn.ua/article/1838-narodnyy-rukh-ukrayny-kakystorycheskoe-yavlenye

5 Кормич, Л.І., Шелест, Д.С. (2004). Громадсъкі об’єднання та політичні партї сучасної України. Київ: Авріо, 61.
} 
вільне об'єднання громадян, яке сприяє розвиткові їх політичної, соціальної, трудової активності й самодіяльності, задоволенню і захисту їх багатогранних інтересів і запитів, діє відповідно до завдань і цілей, закріплених у їхньому статутіб. Отже, як громадське об’єднання НРУ створювався насамперед для задоволення інтересів своїх членів. Для розуміння пріоритетів у цих інтересах варто згадати, що життя в умовах радянської влади визначалося подвійними стандартами і мало два пласти: офіційна пропаганда та ідеологічні легенди та діаметрально протилежна реальність. Тому виникнення Народного руху - це закономірність переходу кількості накопиченого в країні негативу у нову якість усвідомлення себе людей, в яких пробудилась гідність Разом з тим, поява згаданого громадського об'єднання відбувалася на тлі загального національного ренесансу, тому відродження української національної свідомості стало одним з головних мотивів інтеграції громадян навколо Народного Руху України.

Не слід ігнорувати й демократичний контекст виникнення НРУ. Не випадково, виникнення такої громадсько-політичної організації як Народний Рух України не можна розглядати поза їі контекстом, з одного боку, а з іншого - ігнорувати сам факт становища української нації на той час. Тому особливої уваги вимагає аналіз двох взаємозалежних аспектів - загальнодемократичного та національного у процесі кристалізації рухівської ідеї. Таке поєднання в історії українського національного руху не нове. Схожі риси притаманні були українській революції 1917-1921рр. доби Центральної Ради та Директорії8.

Перебудова як офіційна доктрина нового генерального секретаря КПРС Михайла Горбачова оголошувала мету створення «соціалізму з людським обличчям», що на практиці означало відхід від тоталітарних та жорстко авторитарних практик та лібералізацію комуністичного режиму. На середину 1980-х рр. тоталітарна фаза розвитку СРСР була подолана, а в усіх сферах життя різними темпами відбувався процес детоталітаризації. Зокрема, в політичному житті домінували авторитарні риси ${ }^{.}$

Вважається, що передумовою появи у СРСР неформальних громадськополітичних груп та об'єднань у період перебудови став початок боротьби за відміну 6 статті Конституції СРСР, коли проголошувалася відмова від ідеологічних догм і перехід до концепції демократичного соціалізму, що включало пріоритетність загальнолюдських цінностей, ринкову економіку, введення прямих альтернативних виборів секретарів партійних комітетів, свобода угрупувань, федеративний принцип побудови КПРС тощо. При цьому у КПРС намітилися три течії: радикально-реформаторська (Демплатформа), реформістсько-оновлювальна (Марксистська платформа) та традиціоналістська або консервативна. З’явилась тенденція виходу членів КПРС з їі рядів: у 1990 р. на цей крок пішло 2,5 млн. чол. ${ }^{10}$.

Поступово формувалася помітна криза у діяльності Комуністичної партії. У червні 1989 р. ідеологічним відділом ЦК КПУ було проведено соціологічне опитування, яке засвідчило продовження поглиблення процесу втрати довіри до партї та її органів як з боку трудящих, так і комуністів. КПУ підтримувала лише третина населення та $62 \%$ комуністів. Спостерігалася тенденція до звуження соціальної бази - більшість робітників промисловості, будівництва, транспорту, зв’язку проголосували б проти партії - 40\%, і лише 26,3\% підтримали б ії ініціативи ${ }^{11}$.

\footnotetext{
${ }^{6}$ Шведа, Ю.Р. (2005). Політичні партї̈: Енциклопедичний словник. Львів: Астролябія, 77.

7 Барановська, Н. (2010). Суспільно-політичні та соціально-економічні передумови виникнення Руху. У Народний Рух Украӥни: історія, ідеологія та політична еволюція (1989-20о9): Матеріали круглого столу, присвяченого 20-ій річниці створення Народного Руху України за перебудову. Київ, 22 вересня 2009. Київ: Інститут історії України НАН України, 15.

8 Пустовіт, С. (2010). Народний Рух: проблема виникнення. Retrieved from https://www.oldconf.neasmo.org.ua/node/35

9 Бойко, О. (1996). Украйна 1991-1995 рр.: тіні минулого чи контури майбутнъого? Київ: Абрис, 125 .

${ }_{10}$ Барановська, Н. (2010). Вказ. пр., 15.

11 Литвин, В.М. (1994). Політична арена Украӥни: дійові особи та виконавці. Київ: Абрис, 204.
} 
Саме тому український національний рух отримав чергову можливість для розвитку в легальних, а не конспіративних формах як це спостерігалося в роки сталінізму. Це, в свою чергу, дозволяло сподіватися на поступове залучення до нього широких верств населення в міру ослаблення тиску зі сторони партапарату, що уособлював авторитарний режим. На головне питання, яке постало на початку перебудови, хто має очолити цей процес, відповідь була дана очевидна - КПРС як «керівна і спрямовуюча сила радянського народу». Безумовно, початок перебудови активізував процес усвідомлення членами суспільства необхідності захисту власної громадянської та національної гідностіi $^{12}$. Тобто партноменклатура, незважаючи на кризові явища у партії, намагалася будь за що зберегти свій контроль за політичними процесами, хоча змушена була йти на істотні поступки, вчитися грати за новими, більш демократичними правилами.

У березні 1990 р. була скасована 6-та стаття Конституції СРСР про керівну роль КПРС. Одночасно було прийнято закон про громадські об'єднання як основу формування багатопартійної системи в країні. 3 початком лібералізації політичного режиму в ході перебудови і кризи комуністичної ідеології активізувалась поява «неформальних» груп і політичних рухів: міжклубних об’єднань (з весни 1988 р.), Народних фронтів в Естонії (6о тис. осіб), Латвї (115 тис. осіб), Литві («Саюдіс» 189 тис. осіб). Як прояв протестних настроїв частини мислячих людей утворювались народні фронти також в Молдавії, Азербайджані, Казахстані та ін. ${ }^{13 .}$

Незважаючи на істотні зусилля компартійної еліти політичні процеси в радянській імперії поступово виходили з-під контролю ініціаторів перебудови. Свідоцтв тому було чимало: вибори до Верховної Ради СРСР, створення різних напівполітичних організацій («Меморіал», «зелених» та інших), успіхи народних фронтів у Прибалтиці, зміни і відступи в позиціях М.С. Горбачова та його прибічників. Усе це надихало ініціаторів Руху на енергійну роботу по створенню саме того, чого боїться партійний апарат ${ }^{14}$.

В Україні зростання громадської активності розпочинається десь 31988 p. О. Бойко виділяє такі характерні риси та особливості неформальних об'єднань: 1) стихійний процес формування; 2) розбудова неформальних структур «знизу» під впливом народної ініціативи; 3) об’єднання громадян на основі спільних інтересів та особистих стосунків; 4) відсутність на початковому етапі чіткої регламентації діяльності; 5) обрання, а не призначення лідера на основі визнання його авторитету та компетентності у відповідному виді діяльності; 6) консолідація на основі демократичних засад; 7) порівняно значний ступінь самостійності та незалежності від державних та політичних структур 15.

Можна погодитися з С. Пустовітом, що у процесі кристалізації рухівської ідеї виділяються наступні етапи: публічні висловлювання потреби створення народного фронту в підтримку перебудови (липень - вересень 1988 р.); підтримка ідеї письменницькою організацією та робота над програмовими документами (жовтень 1988 16 лютого 1989 рр.); публічне обговорення програмних документів (16 лютого - 9 вересня 1989 р.). 3 самого початку рухівська ідея була синкретичною, поєднувала в собі часом полярні погляди на стратегію й тактику боротьби. Радикальні погляди УГС на початковому етапі не були визначальними. Домінувала поміркована лінія київської інтелігенції, яка передбачала еволюційний поступ ${ }^{16}$.

Виникнення НРУ є історичною закономірністю розвитку націотворчого та демократичного процесу в Україні. Як слушно зауважує Г. Гончарук, поява ідеї Руху була історично, соціально та психологічно обумовленою. Це явище народилось у Києві серед інтелігенції, переважно в письменницькому середовищі і набувало поширення в Україні ${ }^{17}$.

12 Гончарук, Г.І. (1997). Народний Рух Украӥни. Історія. Одеса: Астропринт, 22.

13 Барановська, Н. (2010). Вказ. пр., 15.

14 Гончарук, Г.І. (1997). Вказ. пр., 28.

15 Бойко, О. (1996). Вказ. пр., 24.

16 Пустовіт, С. (2010). Вказ. пр.

17 Гончарук, Г.I. (1997). Вказ. пр., 30. 
Витоки організаційної праці щодо створення НРУ сягають жовтня 1988 р., коли на екологічному семінарі у Спілці письменників України письменник Ф. Бурлачка у своєму виступі вкотре висловив думку щодо створення Народного фронту України на зразок аналогічних неформальних об’єднань, які виникли у Прибалтиці та інших регіонах СРСР 18.

9-11 вересня 1989 року, відбувся Установчий з"їзд громадської організації, яка мала назву «Народний рух України за Перебудову». Ця подія стала знаковою не лише для України, а й для усього Радянського Союзу. 16 лютого 1989 р. у газеті «Літературна Україна» був опублікований проект програми Народного Руху України за перебудову (НРУ), який набув великого суспільно-політичного резонансу. На I (Установчих) Всеукраїнських зборах у м. Києві у вересні 1989 р. було обговорено різноманітні аспекти політичного, соціально-економічного, міжетнічного життя в Україні, дано оцінку ряду знакових для українського народу подій історичного минулого та йшлося про перспективи майбутнього державотворчого життя, ухвалено програму і статут, а також обрано керівні органи НРУ, зокрема головою організації було обрано відомого письменника Івана Драча. У статуті головною метою своєї діяльності НРУ визначав «побудову в Україні демократичного й гуманного суспільства, в якому буде досягнуто справжнього народовладдя, добробуту народу і умов для гідного життя людини, відродження та всебічного розвитку української нації, забезпечення національно-культурних потреб усіх етнічних груп республіки і перетворення республіки у дійсно суверенну Українську державу». Досить швидко НРУ став найпотужнішою політичною опозиційною силою в УРСР і вже 9 лютого 1990 р. його статут було зареєстровано Постановою Ради Міністрів УРСР19.

Народний Рух України виник у 1989 р. як широкий фронт, який об’єднував різні за поглядами ідеологічні сили: від комуністів-реформаторів (які, як і Горбачов, сподівалися на можливість реформування системи) і до правих радикалів. Всіх їх об'єднала ідея зламу тоталітарної системи. Тому недивно, що спочатку в назві Руху фігурували слова «за перебудову». Отже, в написанні нинішньої історії Руху є певна модернізація, коли говорять, що з самого початку це був антикомуністичний рух за незалежність ${ }^{20}$.

Слід підкреслити, що у Народному Русі об’єдналися люди різних політичних переконань - від ліберальних комуністів до тих, хто сповідував ідеї інтегрального націоналізму. Але домінували в організації настрої національної демократії. У перший же рік свого існування Рух організував ряд великих масових заходів, метою яких була боротьба за державну незалежність, відродження української нації, відтворення історії українського народу і державності. Таким чином, Народний Рух України у 19891991 рр. відіграв ключову роль провідника трансформаційних національнодемократичних процесів в Україні, дав початок і основу для виникнення багатопартійності, сприяв демократизації суспільства ${ }^{21}$.

Ідеологічна різнобарвність рухівців, їхня організаційна аморфність, наявність декількох лідерів, відсутність досвіду політичної боротьби робили НРУ сприятливим «спаринг партнером» для верхівки КПУ По суті справи еліті КПУ була потрібна керована, слухняна опозиція і вона їі знайшла в особі лідерів НРУ. За цих обставин необхідна була компромісна формула утворення організованої народної опозицї, яка б органічно поєднала радикалізм політичних неформалів 3 масовістю культурноісторичних та екологічних неформальних об’єднань, злила в єдину політичну еліту досвідчених політичних борців та лідерів нової хвилі. Цією формулою і став «Народний Рух України за перебудову» (НРУ). За оцінками ідеологічного відділу ЦК КПУ,

18 Гай-Нижник, П. (2012). Народний Рух України. В Украӥнська багатопартійність: політичні партї̈, виборчі блоки, лідери (кінець 1980-х - початок 2012 рр.) :Енциклопедичний довідник. Київ: ІПіЕНД ім. І.Ф. Кураса НАН України, 274.

19 Ibid., 277.

20 Гарань, О.В. (1993). Убити дракона (З історї Руху та нових партій Украӥни). Київ: Либідь, 7. ${ }^{21}$ Білецький, В. (2009, 10 вересня). Вказ. пр. 
наприкінці 1989 р. соціальна база НРУ включала близько 12 млн. осіб. Рух став альтернативною, зростаючою і політичною силою22.

Але потім Рух швидко радикалізувався разом з подіями у країні і вже наприкінці 1990 р. на своєму II з'їзді перетворився на правоцентристську антикомуністичну силу, що проголосила своєю метою незалежність України. В історії національновизвольного руху в Україні чільне місце належить НРУ, який постав не лише як громадсько-політичне об'єднання, а як нова форма багатовікової боротьби українського народу за національне визволення. Тобто Рух виник в умовах перебудови як опозиційна політична сила, спрямована проти монополії Комуністичної партії на владу, і став найвпливовішим ії опонентом.

Проте неоднозначні та суперечливі процеси відбувалися у внутрішньому житті НРУ, коли він почав переживати період масовізації. Один з відомих тодішніх рухівських функціонерів Олександр Лавринович нещодавно поділився цікавими спогадами. «Я належав до ініціаторів висунення В'ячеслава Максимовича кандидатом у президенти України від «Руху» у 1991 році. I був щиро здивований, коли значна кількість українських політв'язнів звернулись до Великої Ради Руху з листом-застереженням щодо кандидатури Чорновола. В підсумку рішення про його висування було ухвалене більшістю голосів (57 - «за», 30 - «проти», 4 - «утримались»), а один з авторів цього звернення - Левко Лук'яненко став суперником Чорновола під час виборчої кампанії»23. Роздрібнення електоральної підтримки істотно зменшувало шанси на перемогу В. Чорновола, тому його поразка у боротьбі проти лідера реформаторського крила українських комуністів, тодішнього голови Верховної Ради Леоніда Кравчука була передбачуваною та майже неминучою.

Як зазначає В. Деревінський, українська народно-фронтівська організація - НРУ - зазнала значних трансформаційних змін. У своєму становленні й розвитку пройшла шлях від широкої, погано структурованої громадсько-політичної організації до політичної партії. 3 огляду на низький рівень національної свідомості значної частини населення України, за винятком західного регіону, НРУ не вдалося здобути перемогу на парламентських виборах 1990 р. Лише в трьох областях Західної України демократичний блок отримав більшість в обласних радах, зумівши подолати протидію партноменклатури. Не вдалося НРУ провести до влади свого кандидата В. Чорновола, на президентських виборах 1991 р., набравши лише понад 23\% голосів виборців. Тобто НРУ, на відміну від значної кількості інших народнофронтівських організацій не зумів провести зміну правлячих еліт та розпочати потрібні реформи. Хоча досяг успішної реалізації права українського народу на самовизначення 24.

Парадокс ситуації в Україні порівняно з країнами Балтії та Східної Європи полягав у тому, що розбудову незалежної державності почали здійснювати не ініціатори їі створення, а послідовники противників ії формування. У цьому полягає іронія історичної долі та ключ до розуміння специфіки траєкторії політичного транзиту в Україні.

Після перемоги на президентських виборах Л. Кравчука перед НРУ виникла непроста дилема. У нових політичних умовах перед керівництвом і членами НРУ постало питання, яку позицію має зайняти надалі Рух. Існувало два варіанти виходу 3 цієї ситуації. Згідно першого, який підтримувало керівництво НРУ, він мав залишатися широкою громадсько-політичною організацією, своєрідною коаліцією національно-демократичних партій і громадських організацій. Прихильниками другого виступали безпартійні члени крайових організацій Руху, котрі хотіли перетворити НРУ у політичну партію із збереженням інтеграційного чинника Руху.

22 Литвин, В.М., Смолій, В.А., Левенець, Ю.А. (2007). Украӥна: політична історія. XX - початок XXI cm. Київ: Парламентське вид-во, 925.

23 Лавринович, О. (2018, 7 серпня). Як «Рух» відмовився стати партією влади. День. Retrieved from https://day.kyiv.ua/uk/article/polityka/yak-ruh-vidmovyvsya-staty-partiyeyu-vlady

24 Деревінський, В. (2010). Трансформація НРУ з громадсько-політичної організації в політичну партію. У Народний Рух Украӥни: історія, ідеологія та політична еволюція (1989-20о9): Матеріали круглого столу, присвяченого 20-ій річниці створення Народного Руху України за перебудову. Київ, 22 вересня 2009. Київ: Інститут історії України НАН України, 32. 
Також треба зважати на життєвий шлях та мотивацію керівників НРУ, їхні навички та вміння у питаннях громадсько-політичного менеджменту. За допомогою реформаторської групи в еліті КПУ їм вдалося реалізувати гасло державної незалежності Україн, але для реального державотворення у рухівського керівництва просто не вистачило сил та ресурсів. Вступивши з «маршу в бій», українська інтелігенція разом із звільненими 3 таборів та заслання своїми представниками - Чорноволом, Хмарою, Лук'яненком і братами Горинями, спромоглася реалізувати ту місію Руху, в котрій він як таран рушив останні форпости радянськості в Україні. Проте з причини невкоріненості в соціальне тло і неможливості створення за короткий час згаданих вище структур, Рух зіткнувся з великими труднощами в реалізації другого етапу завоювання реальної політичної влади і очевидно, що так і не зміг виконати цього завдання 25 .

У березні 1992 року відбулася друга подія (яка мала змістовну кореляцію з першою) - третій з”ізд «Руху», під час якого Леонід Кравчук заявив, що підтримує програму Руху й запропонував НРУ стати партією влади. Ця пропозиція була підтримана керівництвом Руху, обраним у жовтні 1990 року на другому з’їзді. В'ячеслав Чорновіл зайняв жорстку позицію протистояння щойно обраному першому президенту України. Розбіжність у цьому визначальному для подальшої долі «Руху» питанні розділила делегатів з“ізду. Щоб запобігти розколу організації було обране колективне керівництво Рухом у складі трьох співголів - І.Ф. Драч, М.М. Горинь, В.М. Чорновіл. Пропозиція ж президента залишилась без відповіді ${ }^{26}$. Враховуючи тогочасну критичну економічну ситуацію (гіперінфляція, шалене економічне падіння), правляча група на чолі з новообраним президентом Л. Кравчуком була змушена маневрувати. Пропозиція лідерам НРУ про партію влади була зроблена не від гарного життя, а під тиском громадськості, яка вимагала швидкого та радикального поліпшення ситуації.

Також варто пригадати, що у Верховній Раді I скликання (1990-1994 рр.) політичне структурування відбулося за ідеологічною та партійною ознакою по лінії «ліві - неліві політичні сили»27. Причому перевага була на боці прокомуністичних сил, так званої «групи 239», яка становила більшість в українському парламенті та несла основну відповідальність за стан справ у державі. Маневр Л. Крачука був викликаний намаганням перенести майбутню політичну відповідальність вже на рухівське керівництво.

По суті справи, як вірно зазначає Д. Коротков, правлячі еліти у республіках колишнього СРСР залишились попередніми, лише змінилися декорації навколо них ${ }^{28}$. Екс-комуністичні еліти шукали ситуативних союзників, щоб розділити з ними відповідальність за невдачі на початковому етапі державотворення та економічних трансформацій. У принципі їм це вдалося, адже окрім В. Чорновола та його найближчого оточення багато рухівців пішло у владу на різні посади.

Таким чином, в історії Руху можна виділити два основні етапи: 1) від заснування в 1989 р. до прийняття Конституції в 1996 р. - активна державотворча діяльність, авторитет серед громадян, Рух - впливова сила в суспільстві та державних структурах; 2) приблизно з 1995 р. - намагання лідерів Руху в соціальній політиці поєднати несумісне: «рух за демократію і свободу та рух за соціальну справедливість» 3 поділом громадян на привілейовані та дискриміновані групи. Наслідок - неперервний спад авторитету, колапс суспільства до системи з пануванням промафіозних кланів 29.

Як стверджує колишній соратник лідера НРУ О. Лавринович, обрана лінія поведінки голови «Руху» В. Чорновола стрімко прискорює неминуче - фактичне відхо-

25 Каспрук, В. (2009). Чому Рух так і не став провідною політичною силою в Україні? Радіо Свобода. Retrieved from https://www.radiosvoboda.org/a/1818227.html

26 Лавринович, О. (2018, 7 серпня). Вказ. пр.

27 Кукуруз, О.В. (2010). Політична опозиція в Украӥні та Польщі: порівняльний аналіз. Київ: Наукова думка.

${ }^{28}$ Коротков, Д.С. (2012). Політична еліта Украӥни: становлення і розвиток у виборчому процесі Украӥни. Харків: Вид-во ХНЕУ, 71.

29 Кравчук, О. (2009). Злет і занепад Руху: плани, результати та уроки. Універсум, 5-6 (187188), 59 . 
дження з політичної арени у історію наймасовішого політичного утворення новітньої Українизо. Прикро, що на відміну від Естонії, Латвії, Литви, Молдови, де у 1992-1993 роках юридично припинили своє життя Народні Фронти і Саюдіс, в Україні досі маргінальні політики використовують юридично зареєстровану назву - «Народний Рух України» до дрібного утворення, яке давно не має нічого спільного із історичним явищем, яке стало рушійною силою на шляху до державної незалежності Україниз1. Отже, головним історичним наслідком діяльності НРУ як масового громадського об’єднання було проголошення державної незалежності України, у той час як здобутки його спадкоємиці - політичної партї̈ «Народний Рух України» є значно скромнішими, адже слід наголосити, що у теперішньому столітті вона жодного разу самотужки не проходила до Верховної Ради України, а їі кандидати дуже рідко вигравали вибори на мажоритарних округах. Проте згадана партія існує і проголосила певні програмні принципи, які вона сповідує протягом доволі помітного відрізку часу.

Програмні засади партії «Народний Рух України» на сучасному етапі. Головною метою діяльності партії Народний Рух України на сучасному етапі є утвердження державної незалежності України та розбудова української національної демократичної держави. Гасло Народного Руху України: «Державність, демократія, реформи!». У ньому зосереджені основні цінності ідеології Руху.

Рух інтерпретує Україну як національну державу, яка виникла внаслідок самовизначення української нації, що гарантує її право на утворення суверенної національної держави і самостійне визначення форм своєї національно-державної організації. Народний Рух України вважає, що перспективною формою правління для України $\epsilon$ «парламентсько-президентська» республіка. Рух виступає за постійний громадський контроль за діяльністю апарату держави шляхом оприлюднення звітності за результатами роботи його органів, отримання поточної інформації про його діяльність завдяки прозорості й публічності дій органів державної влади та місцевого самоврядування.

Щодо економічної частини програми партії НРУ, то вона сконцентрована у такому постулаті: «Економічною основою політичної системи України має бути вільна, багатоукладна, ринкова соціально орієнтована національна економіка. Головні чинники ï становлення - цілковита гарантованість та недоторканність приватної власності на майно, засоби підприємництва, землю, капітальні об'єкти, технології, фінанси. Держава повинна розглядатися як рівноправний суб'єкт приватної власності»32.

НРУ, згідно зі статутними документами, ставить перед собою такі завдання: а) сприяти перетворенню України у національну демократичну правову державу, покликану забезпечити вільний розвиток особистості, захист прав людини і нації, безперешкодне здійснення демократичних свобод; б) домагатися побудови в Україні соціально-орієнтованої ринкової економіки з пріоритетом приватної власності; надійного захисту інтересів виробників і споживачів; високого життєвого рівня; інтеграції України в європейську та світову економічні системи; в) сприяти духовному відродженню української нації, всебічному розвиткові української мови і культури, подоланню наслідків політики русифікації, відродженню історичної пам'яті і національної свідомості громадян України; г) сприяти захисту і примноженню культурних, політичних та господарських традицій українського народу, відстоювати християнські та загальнолюдські цінності; недоторканність особи та приватної власності, гармонійну взаємодію особи, родини, нації, суспільства та держави; г) сприяти всебічному розвиткові мов і культур національних меншостей та етнічних груп, що проживають на території України, стояти на захисті їхніх життєвих прав та інтересів; д) надавати допомогу українцям в інших державах у їхньому прагненні до збереження

\footnotetext{
зо Лавринович, О. (2018, 7 серпня). Вказ. пр.

${ }^{31}$ Ibidem.

32 Гай-Нижник, П. (2012). Народний Рух України. В Украӥнська багатопартійність: політичні партї̈, виборчі блоки, лідери (кінець 1980-х - початок 2012 рр.) :Енциклопедичний довідник. Київ: ІПіЕНД ім. І.Ф. Кураса НАН України, 279.
} 
власної національної самобутності, розвитку їхньої культури, освіти; сприяти їхнім культурним та економічним зв'язкам з Україною; сприяти поверненню українців, які того бажають, на їхню історичну батьківщину; е) відстоювати національні інтереси України, домагатися гарантій безпеки їі громадян і прагнути побудови безпечного i стабільного громадянського суспільстваз3.

Партія «Народний Рух України» підтримує зв’язки з Унією Вольності (Республіка Польща), Союзом Вітчизни Литовських Консерваторів, Pro Partia (Естонська Республіка), Союзом Вітчизни і Свободи (Латвійська Республіка), Білоруським Народним Фронтом, Демократичною партією США, Республіканською партією США, Угорським Демократичним Фронтом (MDF), Консервативною партією Великобританії, Християнсько-демократичним Союзом (Федеративна Республіка Німеччина), Народною Партією (Австрійська Республіка), Європейською Демократичною Унією (ЄДУ) та ін.

Отже, можна констатувати, що Народний Рух України на сучасному етапі перетворився на класичну національно-консервативну партію, яка чітко позиціонує себе як поміркований захисник України як національної демократичної правової держави. Такі ідеї мають прихильників серед українських виборців, але відсутність харизматичних лідерів та спікерів у сучасній партійній еліті НРУ, брак фінансових, організаційних, креативних та кадрових ресурсів зумовлює існування Народного Руху України на маргінесі політичного життя нашої країни.

Оцінки діяльності Народного Руху України. Серед оцінок діяльності Народного Руху України можна виділити два кластери: романтичний та прагматичний. Перший грунтується на визнанні безперечно вагомого, а може й вирішального внеску НРУ у справу розбудови Української держави. Прагматичні оцінки враховують фактичну роль контр-еліт у розподілі владних та економічних ресурсів на пострадянському просторі.

Романтичну групу оцінок можна відобразити думкою Анатолія Рябоконя. «Тепер 3 упевненістю можна сказати, що виникнення організації, яка згодом трансформувалася у політичну партію, стало початком кінця Радянської імперії і влади комуністів. Тільки з виникненням НРУ перед імперією постала загроза їі розпаду, а перед комуністичними керманичами Радянського Союзу - втрати влади. Адже аналітики комуністичної партії розуміли, що організація, непідконтрольна КПРС, яка, згідно з Конституцією СРСР вважалася керівною і спрямовуючою силою, неодмінно очолить національновизвольний рух, візьме на озброєння ідею державного суверенітету України»34.

Прагматичні оцінки діяльності контр-еліт на пострадянському просторі, зокрема в Україні - НРУ, можна репрезентувати конспірологічною версією французької вченої Елен Блан. У своєму дослідженні, яке вона провела у книзі «Родом з КДБ. Система Путіна», Е. Блан наводить переконливі докази стосовно того, що перебудову і подальші парадемократичні процеси в країнах колишнього СРСР планувала і впроваджувала радянська еліта, а виконавцем виступав КДБ на чолі зі всесильним шефом Юрієм Андроповим і його наступниками. Михайло Горбачов у цьому сенсі був лише виконавчим менеджером цього дійства, а ніяк не головною особою35.

Аналізуючи радянську історію другої половини XX ст., Елен Блан вказує на збільшення ролі у цей період корумпованого бюрократичного апарату, кримінальних угруповань та спеціальних служб, які фактично стали формальними та неформальними господарями радянської країни. КДБ отримав під свій контроль практично усю тіньову економіку країни, вправно маніпулюючи політичними гравцями та здійснюючи процес «мирного» розвалу СРСР. Головною причиною перебудови Елен Блан вважає потребу КДБ та керівництва Кремля у легалізації в очах Заходу й

33 Гай-Нижник, П. (2012). Народний Рух України. В Украйнська багатопартійність: політичні партї̈, виборчі блоки, лідери (кінець 1980-х - початок 2012 рр.): Енциклопедичний довідник. Київ: ІПіЕНД ім. І.Ф. Кураса НАН України, 279.

34 Рябоконь, А. (2014, 1 жовтня). Народний Рух України - історія, чи перспектива? Трудова слава, С. 1.

35 Блан, Е. (2009). Родом із КГБ. Система Путіна. Київ: Темпора, 112. 
отриманні кредитів на модернізацію економіки. Дезінформаційна кампанія, яка була вдало проведена кремлівським керівництвом, дала можливість безкарно вивозити за кордон не тільки кошти СРСР, але й частину щедро наданих кредитів ${ }^{6}$.

Ця версія абсолютно вписується у концепцію компромісної народної опозицї по відношенню до кадрів КПУ, роль якої фактично виконав в Україні НРУ. Тобто Народний Рух був використаний спецслужбами та верхівкою КПУ для побудови «національної квартири», яка б гарантувала їм самостійний розподіл майбутніх капіталів та безпеку по відношенню до буремної тоді Росії на чолі з Б. Єльциним. Українська партійна еліта пішла шляхом косметичних змін $і$ відмови від комуністичної ідеологї̈ задля збереження влади в нових історичних умовах. Таким чином, говорячи про те, чому ж все-таки Народний Рух України не зміг досягти максимальних цілей можна констатувати, що ця організація, хоча й очолювана самовідданими синами і патріотами України, не змогла виконати своєї місії до кінця з причини недостатньої підготовки, але й, і можливо й головним чином, з причини протистояння їй набагато сильнішої і більш організованої партноменклатурно-кадебістської системи, в котрої на руках були всі козирі37.

Головне питання, пов'язане з Народним Рухом України полягає у тому: На скільки він був самостійним політичним суб'єктом не за формальними ознаками, а дефакто? А з цього питання випливає наступне: На скільки Рух був дієспроможним політичним суб’єктом, щоб виконати роль не тільки офіційного детонатора комуністичного режиму в Україні, але й демократичної партії влади? Згідно конспірологічної версії керованої компромісної опозиції вочевидь НРУ був об’єктом постійних маніпуляцій з боку на порядок краще організованих КПУ та КДБ, які всіляко намагалися локалізувати та обмежити реальний вплив рухівців на політичні процеси в Україні. Компартійна та спецслужбістська номенклатура у підсумку використали НРУ у своїх цілях, дозволивши йому тільки те, що не зачіпало їх життєво важливих інтересів. Фактично НРУ виступив у ролі «вітрини» змін, прапору унезалежнення, у той час як реальна влада та реальні капітали залишилися у руках колишніх компартійців, комсомольців та представників спеціальних служб.

На користь даної оцінки виступає й факт відмови керівництва НРУ, зокрема В. Чорновола, на пропозицію новообраного тоді президента Леоніда Кравчука стати «партією влади» у березні 1992 року на третьому з”ізді «Руху»38. Оце самообмеження та псевдоромантизм й зіграли з Народним Рухом України злий, у певному сенсі роковий жарт. Тобто самі очільники Руху своєю нерішучістю й визначили його поступове скочування на маргінес політичного процесу в Україні. 3 іншого боку, НРУ майже оптимально провів акції демонтажу тоталітарного режиму на теренах $\mathrm{i}$, що особливо важливо, без людських втрат 39.

Виконавши цю історичну місію, на другому етапі, на котрому необхідно було взяти всю повноту влади в свої руки і приступити до розбудови державних і суспільних інституцій, НРУ не зміг повністю акумулювати підтримку українських громадян, щоб прийти до влади, а далі крок за кроком втратив свій вплив у політиці та суспільстві і нині лише перебуває на маргінальних позиціях. Що, очевидно, не відповідає великому потенціалу народно-демократичних прагнень українського народу40.

Перехопивши ідейну естафету з втомлених рук попередників, Народний Рух України в інших історичних умовах спромігся зорганізуватися й очолити визвольну хвилю українського народу за незалежність, та зіткнувся з неймовірними труднощами на шляху розбудови державності та добробуту населення. Складнощі ці - передусім економічні, соціальні, національні, духовні, політичні наслідки столітніх поневолень;

\footnotetext{
36 Блан, Е. (2009). Родом із КГБ. Система Путіна. Київ: Темпора, 117.

37 Каспрук, В. (2009). Чому Рух так і не став провідною політичною силою в Україні? Радіо Свобода. Retrieved from https://www.radiosvoboda.org/a/1818227.html

38 Лавринович, О. (2018, 7 серпня). Вказ. пр.

39 Каспрук, В. (2009). Вказ. пр.

40 Ibidem.
} 
польського, австрійського й особливо російського колоніального пригноблення, які залишались не тільки в матеріальному бутті народу, а в духовній та моральнопсихологічній сферах, в свідомості українців41.

Разом $з$ тим, необхідно погодитися з В. Білецьким, що Народний Рух України виконав свою основну програмну мету - проголошення України незалежною державою. Це було досягнуто як зусиллями цілої плеяди яскравих особистостей, так (більшою мірою) широких українських мас - інтелігенції, робітників, селян безвідносно до їх колишньої партійної приналежності (позапартійності). Саме в цьому об’єднанні зусиль українського народу заради досягнення стратегічної мети полягає роль і суть Народного Руху України як видатного історичного явища 2 .

У підсумку слід наголосити, що Народний Рух України як масове явище громадсько-політичного життя $\epsilon$ прикладом національно-визвольного руху української нації з усіма вадами іiі становлення. НРУ є віддзеркаленням загальної дієспроможності українського народу у питаннях суверенного державотворення. Тоталітарне минуле, втрата генофонду внаслідок голодомору початку 30-х років XX століття, ментальні девіації, втрата національної самоідентифікації зумовили істотні ускладнення у процесі формування модерної української нації, що позначилося й на діяльності її авангарду наприкінці 1980-х - початку 1990- х в особі НРУ. Проте, історія створення і діяльність Руху має важливе значення і для перспективи розвитку України, в першу чергу - подальшому поширенні української національної ідеї43.

Висновки. Підсумовуючи сказане, слід наголосити на наступному. Появу Народного руху України слід розглядати через призму загальносвітової тенденції «оксамитових революцій», які відбулися у Східній Європі наприкінці XX століття. НРУ став своєрідним аналогом польської «Солідарності» та інших рухів народнофронтівського типу, які виступили головними рушійними силами цих революцій.

Виникнення Народного руху України - це історична закономірність, яка мала національно-визвольний та загально демократичний контекст. 3 одного боку НРУ акумулював енергію національного ренесансу українців та виступив головною рушійною силою національної революції. 3 іншого боку, Народний Рух виконав роль детонатору комуністичного режиму, позбавивши КПУ монополії на політичну владу. Саме під тиском НРУ та інших народних фронтів у березні 1990 р. була скасована шоста стаття Конституції СРСР про керівну роль КПРС у суспільстві. Одночасно було прийнято закон про громадські об'єднання, який відкрив можливість для формування багатопартійної системи в Радянському Союзі та зокрема в Україні.

Криза у діяльності Комуністичної партії у середині 80-х років спричинила лібералізацію радянського жорстко авторитарного режиму та уможливила легальні, а не конспіративні форми діяльності українського національного руху, який головним чином репрезентував НРУ.

Народний Рух України спочатку виник у письменницькому середовищі Києва та отримав поширення в усій Україні. Це наклало відбиток на основні форми та методи діяльності цієї організації. Ідеологічний плюралізм рухівців, їхня організаційна аморфність, наявність декількох лідерів, відсутність досвіду політичної боротьби спричинили неготовність взяти усю повноту влади та виступити демократичною партією влади за нових історичних умов.

В історії НРУ можна виділити два основні етапи: 1) від заснування в 1989 р. до прийняття Конституції в 1996 р. - активна політична діяльність, великий вплив на державотворчий процес; 2) з 1996 р. - спадання активності та втрата впливу на основні політичні процеси.

Основним історичним наслідком діяльності НРУ як масового громадського об’єднання було проголошення державної незалежності України, у той час як досяг-

${ }^{41}$ Гончарук, Г.I. (1997). Вказ. пр., 12.

42 Білецький, В. (2009, 10 вересня). Вказ. пр.

43 Рябоконь, А. (2014, 1 жовтня). Вказ. пр. 
нення політичної партії «Народний Рух України» є значно скромнішими: у XXI столітті вона жодного разу самотужки не проходила до українського парламенту.

Народний Рух України став компромісною формулою утворення організованої народної опозиції для кадрів КПУ, які використали його для проголошення державної незалежності України, тобто для відмежування від союзної компартійної еліти, а потім локалізували діяльність НРУ через штучні розколи та ін.

Специфіка політичного транзиту в Україні полягає в тому, що основним суб’єктом державотворення виступив не його фундатор - НРУ, а компартійна номенклатура, яка використала гасло розбудови національної держави у своїх вузько корпоративних цілях, насамперед для самостійної легалізації капіталів.

За розвитком демократизації, яку започаткував Народний Рух, Україна опинилася на проміжній позиції між повністю контрольованою старою номенклатурою авторитарною Росією і балтійськими та східноєвропейськими країнами, котрі зуміли у стислі терміни пройти демократичний транзит.

Геополітичне значення Народного Руху полягає в тому, що питома вага України для СРСР була вирішальною умовою існування цього політичного утворення. Вихід зі складу Радянського Союзу країн Балтії не мав критичного значення для союзної держави, а вихід другої за потугою республіки - України остаточно зруйнував радянську імперію. Тому намагання усіх радянських та російських правителів утримати Україну в орбіті свого впливу мотивується ними прагненням зберегти саму російську державність, яка не усвідомлюється ними у неімперській формулі. Цим пояснюється категоричне неприйняття росіянами будь-яких носіїв української національної ідеї, навіть у її поміркованій версії, яку репрезентував Народний Рух України.

На сучасному етапі Народний Рух України перетворився на класичну національно-консервативну партію, яка ставить за мету розвиток України як національної демократичної правової держави.

\section{REFERENCES}

Baranovska, N. (2010). Suspilno-politychni ta sotsialno-ekonomichni peredumovy vynyknennia Rukhu. [Socio-political and socio-economic preconditions for the emergence of the Movement]. In Narodnyi Rukh Ukrainy: istoriia, ideolohiia ta politychna evoliutsiia (1989-20o9): Materialy kruhloho stolu, prysviachenoho 20-i richnytsi stvorennia Narodnoho Rukhu Ukrainy za perebudovu. Kyiv, 22 veresnia 2009. Kyiv: Instytut istorii Ukrainy NAN Ukrainy, 13-28. [in Ukrainian]

Biletskyi, V. (2009, September 10). Narodnyi Rukh Ukrainy yak istorychne yavyshche. [The People's Movement of Ukraine as a Historical Phenomenon] Novosti Donbassa. Retrieved from http://novosti.dn.ua/article/1838-narodnyy-rukh-ukrayny-kak-ystorycheskoe-yavlenye Ukrainian]

Blan, E. (2009). Rodom iz KHB. Systema Putina. [Originally from the KGB. Putin's system]. Kyiv: Tempora. [in Ukrainian]

Boyko, O. (1996). Ukraina 1991-1995 rr.: tini mynuloho chy kontury maibutnoho? [Ukraine 19911995: shadows of the past or contours of the future?] Kyiv: Abrys. [in Ukrainian]

Chyhrinov, V.I. \& Polishchuk, I.O. (2006). Derzhavotvorcha tradytsiia Ukrainy: politykokulturnyi vymir. [The state-building tradition of Ukraine: a political and cultural dimension]. Kharkiv: KhIBM. [in Ukrainian]

Derevinskyi, V. (2010). Transformatsiia NRU z hromadsko-politychnoi orhanizatsii v politychnu partiiu. [Transformation of the NRU from a public-political organization into a political party]. In Narodnyi Rukh Ukrainy: istoriia, ideolohiia ta politychna evoliutsiia (1989-2009): Materialy kruhloho stolu, prysviachenoho 20-i richnytsi stvorennia Narodnoho Rukhu Ukrainy za perebudovu. Kyiv, 22 veresnia 2009. Kyiv: Instytut istorii Ukrainy NAN Ukrainy, 29-38. [in Ukrainian]

Hay-Nyzhnyk, P. (2012). Narodnyi Rukh Ukrainy. In Ukrainska bahatopartiinist: politychni partii, vyborchi bloky, lidery (kinets 1980-kh - pochatok 2012 rr.) [The People's Movement of Ukraine. Ukrainian multiparty politics: political parties, electoral blocs, leaders (late 1980s - early 2012)]. Entsyklopedychnyi dovidnyk. Kyiv: IPiEND im. I.F. Kurasa NAN Ukrainy, 274-280. [in Ukrainian]

Haran, O.V. (1993). Ubyty drakona (Z istorii Rukhu ta novykh partii Ukrainy). [Kill the Dragon (From the History of the Movement and New Parties of Ukraine) ] Kyiv: Lybid. [in Ukrainian] 
Honcharuk, H.I. (1997). Narodnyi Rukh Ukrainy. Istoriya. [The People's Movement of Ukraine. History]. Odesa: Astroprynt. [in Ukrainian]

Kalynovskyi, Yu.Yu. (2016). Natsionalna ideia yak tsinnisna determinanta derzhavotvorchoho protsesu v Ukraini. [The national idea as a value determinant of the state-making process in Ukraine]. Visnyk Natsionalnoho universytetu «Yurydychna akademïa Ukrainy imeni Yarolava Mudroho». Seriia: Filosofiia, 1 (28), 98-105. [in Ukrainian]

Kaspruk, V. (2009). Chomu Rukh tak i ne stav providnoiu politychnoiu syloiu v Ukraini? [Why has the Rukh not become a leading political force in Ukraine?]. Radio Svoboda. Retrieved from https://www.radiosvoboda.org/a/1818227.html [in Ukrainian]

Kormych, L.I., Shelest, D.S. (2004). Hromadski obiednannia ta politychni partii suchasnoi Ukrainy. [Public Associations and Political Parties of Modern Ukraine]. Kyiv: Avrio. [in Ukrainian]

Korotkov, D.S. (2012). Politychna elita Ukrainy: stanovlennia i rozvytok u vyborchomu protsesi Ukrainy. [The Political Elite of Ukraine: Formation and Development in the Electoral Process of Ukraine]. Kharkiv: Vyd-vo KhNEU. [in Ukrainian]

Kravchuk, O. (2009). Zlet i zanepad Rukhu: plany, rezultaty ta uroky. [The Rise and Decline of the Movement: Plans, Outcomes and Lessons]. Universum, 5-6 (187-188), 57-69. [in Ukrainian]

Kukuruz, O.V. (2010). Politychna opozytsiia v Ukraini ta Polshchi: porivnialnyi analiz. [Political opposition in Ukraine and Poland: a comparative analysis]. Kyiv: Naukova dumka. [in Ukrainian]

Lavrynovych, O. (2018, August 7). Yak «Rukh» vidmovyvsia staty partiieiu vlady. [How the Rukh refused to become a party of power]. Den. Retrieved from https://day.kyiv.ua/uk/article/polityka/yak-ruh-vidmovyvsya-staty-partiyeyu-vlady [in Ukrainian]

Lytvyn, V.M. (1994). Politychna arena Ukrainy: diiovi osoby ta vykonavtsi. [The political arena of Ukraine: actors and performers]. Kyiv: Abrys. [in Ukrainian]

Lytvyn, V.M., Smolii, V.A. \& Levenets, Yu.A. (2007). Ukraina: politychna istoriia. XX - pochatok XXI st. [Ukraine: A Political History. XX - beginning of XXI century]. Kyiv: Parlamentske vyd-vo. [in Ukrainian]

Patnam, R.D., Leonardi, R. \& Nanetti, R.Y. (2001). Tvorennia demokratii: tradytsii hromadianskoi aktyvnosti v suchasnii Italii. [Creating Democracy: Traditions of Civic Engagement in Modern Italy]. Kyiv: Vydavnytstvo Solomii Pavlychko «Osnovy». [in Ukrainian]

Pustovit, S. (2010). Narolnyi Rukh: problema vynyknennia. [The People's Movement of Ukraine: The Problem of Emergence]. Retrieved from https://www.oldconf.neasmo.org.ua/node/35 [in Ukrainian]

Riabokon, A. (2014, October 1). Narodnyi Rukh Ukrainy - istoriia, chy perspektyva? [The People's Movement of Ukraine - History, or Perspective?] Trudova slava, p. 1 [in Ukrainian]

Shveda, Yu.R. (2005). Politychni partii: Entsyklopedychnyi slovnyk. [Political Parties: An Encyclopedic Dictionary]. Lviv: Astroliabiia. [in Ukrainian]

Ihor Polishchuk,

Yaroslav the Wise National Law University ORCID: https://orcid.org/oooo-Ooo1-6864-4425

\section{The People Movement of Ukraine: Causes and Results of Activities}

Ukraine demonstrates a rather specific trajectory of political transit in the post-Soviet and, in general, post-socialist region. The non-linearity and contradiction of this process, the presence of visual reversals or rollbacks in the path of Ukraine's democratization make one think again about the genesis of the new national liberation movement and the main factors that have caused the independence and rejection of the pro-communist concept of development. The People's Movement of Ukraine as a mass anti-communist and anti-imperial subject in the second-largest Soviet republic undoubtedly acts as the main driving force behind the revolutionary events at the turn of the 1980 s and 1990 in the former USSR. The article reveals the causes, main periods and consequences of the People's Movement of Ukraine. The programmatic foundations of the People's Movement of Ukraine party are considered at the present stage. There are two main stages in the history of the NRU: 1) from the foundation in 1989 to the adoption of the Constitution in 1996 - active political activity, great influence on the state-making process; 2) since 1996 
- the decline of activity and the loss of influence on the main political processes. In general, the People's Movement of Ukraine has become a compromise formula for the formation of an organized people's opposition for the Communist Party. The main historical consequence of the NRC's activity as a mass public association was the proclamation of Ukraine's state independence, but it failed to become a democratic party in power under new historical conditions. At the present stage, the People's Movement of Ukraine has become a classic national-conservative party, which has little influence on the current political process in Ukraine.

Keywords: People's Movement of Ukraine, perestroika, independence of Ukraine, democratization, political transit, geopolitics 